\title{
WALT WHITMAN'S EARLY \\ FICTION IN PERIODICALS: \\ OVER 250 NEWLY DISCOVERED REPRINTS
}

\author{
Stephanie M. Blalock
}

In An INTRODUCTORY NOTE to Collect, Walt Whitman composed "a special word"- a disclaimer-about the short fiction he reprinted in "Pieces in Early Youth," stories that he had written approximately fifty years earlier, when, according to the poet, "I tried my 'prentice hand at recording-(I was then quite an 'abolitionist' and advocate of the 'temperance' and 'anti-capital-punishment' causes)."' Whitman went on to sum up his feelings about those early short stories, writing: "My serious wish were to have all those crude and boyish pieces quietly dropp'd in oblivion-but to avoid the annoyance of their surreptitious issue ... I have, with some qualms, tack'd them on here."2 Whitman suggests, therefore, that he is reluctantly, even if purposefully, reprinting the tales. In another, more amusing anecdote, Whitman similarly distanced himself from Franklin Evans, or The Inebriate: A Tale of the Times, his only novel, written at the age of twenty-three. In 1888, just four years before his death, Whitman explained to his friend and biographer Horace Traubel how he came to write Franklin Evans. Reflecting on the temperance tale he had composed in 1842, Whitman stated, "I set to work at once ardently on it (with the help of a bottle of port)." " This was not the only time Whitman insisted that intemperance inspired the volume's sobering principles. According to a friend of the poet's, J. G. Schumaker, Whitman once claimed to have written the book under the influence of gin cocktails. In yet another version of the story, Whitman said he relied on whiskey cocktails to finish the novel. ${ }^{4}$ Whitman would also call Franklin Evans "damned rot-rot of the worst sort - not insincere, perhaps, but rot, nevertheless." ${ }^{5}$ But rot or not, despite the poet's dismissal of the novel, it sold approximately 20,000 copies, which was more than any of the other works Whitman published in his lifetime. ${ }^{6}$

The sizable readership of Franklin Evans, its sensational plot events, and a recent scholarly edition have led to new critical perspectives on the novel. Whitman's short fiction, however, has long been neglected even though, as I hope to show, the publication history of those pieces 
may help explain the popularity of the poet's temperance novel. There has been less attention given to Whitman's short fiction not only because of the poet's own desire to allow it to be "dropp'd in oblivion," but also because, in the words of Whitman's biographer Henry Seidel Canby, "'melodramatic' is too weak a word to describe its incidents and characters, 'sentimental' too mild to define its morality, and 'tripe' too gentle a name for its eloquence." A All of Whitman's short stories were, as Canby succinctly put it: "pretty terrible," and Thomas L. Brasher, editor of The Early Poetry and the Fiction, a volume of The Collected Writings of Walt Whitman, even went so far as to state, "The plain fact is that Whitman had no talent for fiction."

Until now, there has been little evidence to support a more favorable statement that a proud young Walter Whitman made about those very short stories in a June 14,1842 , letter to Nathan Hale, Jr., editor of the Boston Miscellany: "My stories, I believe, have been pretty popular, and extracted liberally." "Here, it is imperative to acknowledge that scholars, most notably Thomas L. Brasher, have collected citations for previously discovered reprints of Whitman's early fiction and his temperance novel - in both periodicals and books. Brasher's The Early Poetry and the Fiction provides citation information for about twenty-four reprints of the stories in periodicals. ${ }^{10}$ But as David S. Reynolds, author of Walt Whitman's America: A Cultural Biography points out, "Death in the School-Room," Whitman's earliest short story, first published in the Democratic Review in August 1841, "would go on to become one of his most popular works. It was reprinted six different times in his lifetime." 11 Taking "Death in the School-Room" as an example, this modest number of reprints is certainly evidence of interest by editors and readers in the poet's fiction, but this publication history does not suggest widespread popularity or liberal extraction and reprinting in periodicals.

Based on what is known about Whitman's short fiction, then, it is difficult to imagine him in his twenties as anything but a journalist and little-known short story writer largely unsuccessfully, but nonetheless enthusiastically, attempting to make a name for himself as a fiction writer in the period's literary publications. The poet wrote and published short stories for at least seven years-between 1841 and 1848 - and during this time, he produced approximately twenty-two works of short fiction. ${ }^{12}$ These stories, along with Franklin Evans and The Half-Breed are collected in The Early Poems and Fiction. One piece from this volume, "The Madman," remained unfinished; the same is true for a story entitled "The Fireman's Dream: With the Story of His Strange Companion, A Tale of Fantasie," which first came to light when Herbert Bergman was doing research for collected volumes of Whitman's journalism. ${ }^{13}$ Only two chapters of each work are known to have appeared in print despite 
explicit indications that each would be "continued."14 All of Whitman's stories, including the two unfinished pieces, were originally published in periodicals. The first known appearances of Whitman's short stories have been established as "in 1841 (four stories), 1842 (six), 1843 (one), 1844 (five), 1845 (six), 1848 (one), [and] unknown (one)." Of these, "[n] ine were first published in the Democratic Review, three in 1841-five in 1842, and one in 1845; four in The Aristidean, in 1845; one in the New York Washingtonian and Organ (1843); two (1844) in the Columbian Magazine, one in The Rover (1844); one in the American Review (1845); and one in the Union Magazine of Literature and Art (1848)." "The Fireman's Dream" was published in the Sunday Times $\mathcal{E}$ Noah's Weekly Messenger in $1843 .{ }^{16}$ As this bibliography will show, however, new publication information regarding the original printing of at least two stories - "Little Jane" and "The Boy-Lover" — will need to be added to this timeline.

With the increasing availability of digitized copies of newspapers and magazines, there is an unprecedented opportunity to search for reprints of Whitman's short fiction and to look for earlier printings of the stories. It is possible to search for continuations of those presumably unfinished pieces, even as there is also a chance to learn about Whitman's popularity and his reception as a nineteenth century writer of American fiction. ${ }^{17}$ Indeed, searches of databases-ranging from American Periodicals Series Online, 1740-1900 and $19^{\text {th }}$ Century U. S. Newspapers to America's Historical Newspapers and the Chronicling America: Historic American Nerwspapers electronic archive-for the individual titles (and variants of those titles), the names of various characters, and for particular phrases from each of Whitman's works of short fiction have yielded publication information for approximately 266 previously unknown reprints and, in some cases, what may be newly discovered first printings of those tales. ${ }^{18}$

Two of the most significant items that appear for the first time in the following bibliography are the earliest known printings of a tale embedded in Franklin Evans - later titled "Little Jane"-in the New York Evening Post and the New York Sun, where it was published as "The Reformed" during the week prior to the appearance of the novel. Other important discoveries include: the earliest known reprinting of the other tale embedded within Franklin Evans - later titled "The Death of Wind-Foot" - in the February 1, 1843, edition of the Wiskonsan Enquirer, where it was published as "The Unrelenting"; the earliest version of the story that would later be titled "The-Boy Lover" in The Nerw Mirror in December 1843, where it was published as "The Love of the Four Students: A Chronicle of New York"; and what are, at this time, the only known reprints of "Bervance, or Father and Son" to be published in nineteenth century American periodicals. This bibliography also brings 
to light five reprints published in international periodicals, the earliest of which is "The Death of Wind-Foot," which was printed in Tasmania in the Colonial Times and Tasmanian on April 7, 1846. Whitman's "The Tomb-Blossoms" appeared at least twice in British publications, once in July 1842 in The Great Western Magazine and Anglo-American fournal and once in July 1881 as "The Tomb Flowers"-a condensed version of the tale - that was published in Our Boys and Girls: A Monthly Magazine and seemingly intended for an audience of young readers. Whitman's "A Legend of Life and Love" was reprinted in the Stanstead Fournal in Rock Island, Stanstead, Canada, on August 13, 1846, and the rarely reprinted story "The Angel of Tears" appeared in London in The Lamp, A Weekly Catholic Fournal of Politics, Literature, Science, the Fine Arts on December 16, 1854. In addition to these pieces, this bibliography draws attention to the surprising numbers of reprints of Whitman's most popular stories. "Death in the School-Room. A Fact" has been reprinted at least 104 times in periodicals and "A Legend of Life and Love" has had at least 71 periodical reprints.

Among the items that should be examined in detail here are the first printings of "The Reformed," a tale that would become part of Franklin Evans, but was originally published for the purposes of advertising and bolstering the sales of Whitman's novel. Before this tale became known as "Little Jane" when Whitman published it in the December 7, 1846, edition of the Brooklyn Daily Eagle, it was printed in at least two different New York newspapers. Both known printings occurred before Park Benjamin's New World issued Franklin Evans as an extra series on November 23, 1842. ${ }^{19}$ The story is related by the character of Mr. Marchion, who acts as a mentor to the eponymous protagonist Franklin Evans. Marchion hopes that by narrating his own reformation from a youthful, drunken "brawler" to a sober citizen following the death of his younger sister "Little Jane," he will lead Evans to abstain from alcohol and join the temperance movement. The New York Sun printed "The Reformed" on November 17, 1842, and the editor explained the early appearance of this part of the novel in a brief, but informative note:

We are permitted to extract the following beautiful sketch from a forthcoming novel to be published next week. . . It is written by Mr. Whitman, an author whose eloquent pen is in this work devoted to a most worthy cause-the cause of temperance. ${ }^{20}$

Two days later, on November 19, 1842, "The Reformed" also appeared in The Evening Post, and again, the editor acknowledged that the extract came from a soon-to-be published novel by "Mr. Whitman" and promised that the work would "be read with interest." 21

These excerpts almost certainly functioned as both previews of Whitman's novel and as publicity for the forthcoming Nerw World extra 
edition. The choice to extract this tale from Franklin Evans would seem to imply that "The Reformed" is representative of the plot, and both the excerpt and the novel as a whole do emphasize the themes of temperance, especially the Washingtonian temperance society's reliance on the narration of former drunkards' personal conversion experiences to further the temperance cause. In fact, Mr. Marchion's tale constitutes just such an "experience" and foreshadows Franklin Evans' own efforts at reformation after the young man is introduced to New York's "musical drinking houses" when he moves to the city for the first time. ${ }^{22}$ Furthermore, just as "The Reformed" is a first-person narrative related by Mr. Marchion himself, the novel Franklin Evans is told from Evans' perspective as he describes his impressions of urban barroom scenes and his struggles, first to adapt to life in the city and, later, to adhere to a temperance pledge. But "The Reformed," which centers on the transformative power of a religious story given to a drunken brother as a memento by his dying younger sister, does not seem to entirely prepare readers for the complicated and melodramatic plot of Whitman's novel. After all, Franklin Evans includes nightly trips to New York barrooms, a failed first marriage, the death of Evans' first wife, a second marriage to a mulatto woman on a Southern plantation, Evans' desire to leave his second wife for an attractive widow, and his second wife's suicide, in addition to descriptions of Evans' own drunken antics. One has to wonder if nineteenth century readers were pleased or disappointed to receive such a temperance novel after reading "The Reformed" as a kind of sneak preview and presumably as a representative abstract of the forthcoming novel.

While "The Reformed" may have contributed to the popularity of Whitman's only temperance novel, the sheer number of recently discovered reprints of other pieces of Whitman's fiction reveals that the poet's stories were also widely read in their own right. This bibliography supports David S. Reynolds's assertion that "Death in the School-Room" was one of Whitman's most popular works. ${ }^{23}$ But these reprints also buttress another of Whitman's own claims in his letter to Nathan Hale, Jr., in which the young author explains, "Several of them [my short stories] in the Democratic Review have received public favor, instance 'Death in the School-Room,' \&c. \&c."24 "Death in the School-Room" was written and published when Whitman was only twenty-two years old, and the story may have emerged from his own experience as a schoolteacher. ${ }^{25}$ An article published in the New York Sun on March 10, 1907, calls the story "a gruesome incident in Long Island country life" that "caught the public fancy, and was widely copied by the provincial press." 26 Whitman's story is the dark tale of a cruel schoolmaster called Lugare, who mercilessly flogs young Tim Barker both for his supposed thievery of fruit from a local farmer's garden 
(Tim is innocent of the crime) and for what Lugare believes is the insolent offense of sleeping in class. The children watch in terror as the schoolmaster cruelly punishes Tim, and it is only after several minutes of inflicting non-stop blows that Lugare, and the class, learn in horror that the schoolmaster has been relentlessly "flogging a corpse"-that of the already deceased child. ${ }^{27}$ The story is thus rife with the schoolmaster's anger and violence, the children's fear, and all the characters' horror, even as those plot elements clearly function to voice a plea for education reform and the abolishment of corporal punishment in the nineteenth century schoolroom.

The publication of "Death in the School-Room" in the Democratic Review was an accomplishment for Whitman. According to Herbert Bergman, "the Democratic Review was the major literary journal of the period, analogous to later journals like The Atlantic Monthly and The Century," and the fact that the story appeared here suggests that its "quality compared favorably" with other works of short fiction in the United States in the nineteenth century. Publication in this prestigious journal also meant that Whitman's name joined a long list of more well-known Democratic Review contributors, including "Hawthorne, Poe, Lowell, Thoreau, Whittier, Bryant, Longfellow, Paulding, [and] Simms." 28 The appearance of "Death in the School-Room" in the reputable journal no doubt increased the chances that other newspapers and magazines would reprint the story. Whitman's insistence on the positive reception of this original publication and his assertion that the story was soon "liberally extracted" in his letter to Hale suggest that he was aware of at least some reprints of the work and its seeming popularity among periodical readers. Whitman, as it turns out, was justified in making such a claim, because by the time of the publication of Franklin Evans on November 23, 1842, "Death in the School-Room" had been reprinted at least sixty-one times in fifty-five cities (including Washington, D.C.) in fifteen states. ${ }^{29}$ In more than half of these cases, the story appeared in part or in whole on the front page of the paper, with the author identified by the initials "W. W." Some editors, then, must have been confident that a title that promised a "death in the school-room" would sell copies of their newspapers, and due to the story's prominent placement and the number of times it was reprinted, it is reasonable to conclude that Whitman's tale was more widely and more often "extracted" than previously imagined.

Whitman's "Death in the School-Room" was not the poet's only often-reprinted story. His second most popular piece "A Legend of Life and Love," which also first appeared in the Democratic Review, was published in July 1842. Joseph Jay Rubin has noted that "A Legend of Life and Love" was reprinted in "Brother fonathan, the Tribune, the Sun, and the Democrat, as late as 7 August 1849." ${ }^{30}$ This tale opens 
with an "Ancient Man," who is the grandfather of two young men, Nathan and Mark. On his deathbed, the grandfather warns them, "“The World is full of deceit. Evil men swarm in every place, and sorrow and disappointment are the fruits of intercourse with them."'31 He further advises the young men, "Do not allow love to come into your life. Love is the ficklest of all things in life."'32 One grandson, Mark, lives his life entirely by his grandfather's advice, while the other, Nathan, follows his own path and proceeds to marry and have children. Nathan and Mark reunite fifty years later - having lived their chosen lives separately - and tell one another what has happened since they were together last. It is then that Nathan reveals what he has learned from refusing his grandfather's advice, telling Mark, "“ [T] he world has misery_-but it is a pleasant world still, and affords much joy to the dwellers." 33 It is difficult, in other words, to be happy if one never risks pain, as Nathan wisely explains, thereby presenting Whitman's moral to his brother and to the readers. This sentimental, yet didactic, tale, with its moral ending, was reprinted at least seventy times during Whitman's lifetime, and it appeared at least forty-eight times between July 1842 and the publication of Franklin Evans in November of the same year. Like "Death in the School-Room," "A Legend of Life and Love" was reprinted primarily in newspapers. It was published in at least forty-three cities in fifteen states during this period of approximately five-and-a-half months alone. Again, in more than half of these publications the story appeared in part or in whole on the front page with the author listed as "W.W." Rubin notes that two of these reprints appeared in the New York Sun and the Tribune, newspapers "with a combined circulation of some 30,000; the story was printed on the papers' front pages during the same week." ${ }^{34}$

Five more of Whitman's short stories were also reprinted-albeit considerably fewer times-before the publication of his novel. "Wild Frank's Return" (November 1841) and "The Tomb Blossoms" (January 1842) were reprinted six and four times, respectively. "The ChildGhost: A Story of the Last-Loyalist" (May 1842) was also reprinted three times, while "Bervance, or Father and Son" (December 1841) the tale of a harsh, unrelenting father and a son driven to insanity-was reprinted at least three times, and "The Last of the Sacred Army" was reprinted once (March 1842). All of these tales would also be reprinted at least once in the years following the publication of Franklin Evans. ${ }^{35}$ What this means is that even before the novel was issued, readers in at least eighteen states and Washington, D. C., had-whether knowingly or unknowingly - encountered Whitman's short fiction. At the same time, it is worth mentioning that the reprinting of Whitman's "Death in the School-Room" and "A Legend of Life and Love" also continued long after November 1842. For example, "A Legend of Life and Love" was reprinted in Jacksonville, Florida, in 1852, and in St. Albans, 
Vermont - this time as "Legend of Life and Love"-in 1857. "Death in the School-Room" was reprinted as "Death in a School Room" at least six times in Wisconsin in 1860, which was about twelve years after Whitman had presumably stopped writing short fiction and was, in fact, the year that Boston publishers Thayer and Eldridge printed the third edition of Leaves of Grass.

One potential meaning of the circulation of reprints of Whitman's fiction is that some of the popularity of Franklin Evans among 1840s readers, along with its high sales figures were not just owing to the potboiler temperance genre that Whitman was writing in or to the success of the Washington Temperance Societies, although certainly these were contributing factors. Scholars must now consider the possibility that readers were intrigued by the preview of the novel they received in the form of a short story titled simply "The Reformed." It might also be worth asking whether newspaper editors and/or even some nineteenth century readers would have recognized the "W. W." of the stories they read in the Democratic Review or in their local newspapers as the "Walter Whitman" whose name appeared on the front page of the extra series as the author of Franklin Evans. ${ }^{36}$ That Whitman authored both the novel and "Death in the School-Room," however, would have been obvious to readers who purchased the "copyright edition" which was issued by J. Wincester as part of the "Books for the People" series and which employed the title Franklin Evans: Knowledge is Power. The Merchant's Clerk, in New York; or the Career of a Young Man from the Country (no date). According to the title page, the writer of the novel is "Walter Whitman, Author of 'Death in the Schoolroom,' Etc. Etc." ${ }^{37}$ If this is the edition issued in 1843, a date that William J. Lulloff suggests for Franklin Evans: Knowledge is Power, then by the beginning of that same year, Whitman's fiction had been reprinted in more than eighty periodicals in eighteen states. ${ }^{38}$

The early printings of "The Reformed" and the previously unknown reprints of many of Whitman's fiction pieces also invite the poet's readers to reconsider his career as both a fiction writer for nineteenth century American periodicals, as well as his simultaneous and, arguably, more successful efforts as a journalist, reporting local happenings for New York newspapers. But most significantly, what this discovery means is that, although Whitman's short stories may have been tossed into what Jean Downey calls "the dustbins of literature" since the nineteenth century, readers of Whitman's fiction in the 1840s and in subsequent decades may not have been so quick to disregard them. ${ }^{39}$ Far from having published his fiction and early poetry in "about twenty different newspapers and magazines," Whitman's short fiction alone-including both originals and reprints - appeared in more than two hundred periodicals. ${ }^{40}$ Yet, even given this highly impressive number of publications 
in periodical literature, "Walter Whitman" has not, at least for today's readers, become as recognizable a name in nineteenth century American fiction as "Edgar Allan Poe" or "Nathaniel Hawthorne." Even so, at least one New York newspaper, the Daily Troy Budget, reprinted six of Whitman's stories: "Death in the School-Room," "Wild Frank's Return," "Bervance, or Father and Son," "The Child-Ghost: a Story of the Last Loyalist," and "A Legend of Life and Love"-all from the Democratic Review - and "The Reformed"- seemingly from the New York Sun. ${ }^{41}$ One of the paper's writers also explicitly expressed a preference for Whitman's fiction. In an article that praised the May 1842 issue of the Democratic Review, the writer enthusiastically declared "Walter Whitman" to be "a favorite with us" and pronounced the "Child-Ghost" a "fine story," suggesting that Whitman's fiction was, in fact, "pretty popular" with the paper's readers and editors alike. ${ }^{42}$ The Daily Budget was not alone in reprinting multiple pieces of fiction by Whitman. Some thirty-one U. S. newspapers and/or journals reprinted at least two of Whitman's tales or reprinted the same tale twice; approximately seven periodicals reprinted at least three; and three reprinted at least four stories. This interest in Whitman's fiction suggests that Whitman or "W. W." was certainly more often reprinted and, perhaps, a more popular fiction writer than has been previously imagined.

This new perspective on Whitman raises important questions about how nineteenth century readers perceived the poet's stories, which blended social reforms like education and temperance with thrilling plot events, proved to be frightening, psychological tales of relationships between fathers and their sons, or, in several cases, followed the adventures of young male friends. At the same time, if Whitman's stories did receive more attention than once believed, it is worth asking again why and how Whitman left fiction writing to pursue poetry. It seems equally productive to reconsider why, late in the poet's life, these stories-albeit by then dated and reflective of views held by a much younger Whitman-had become works that the poet felt he needed to distance himself from instead of seeing them as vital steps (or necessary missteps) toward the making of the poet best remembered for his six editions of Leaves of Grass. Yet, despite Whitman's disclaimer, his ultimate decision to include these "pieces in early youth" in Collect and, therefore, to reprint and to preserve them for posterity does constitute a reclaiming of this early fiction. The hitherto unknown popularity of Whitman's "Death in the School-Room" and several periodicals" reprints of "Wild Frank's Return" might help explain the remarkable gesture of including them in Collect so many years after these stories were written. The seeming lack of reprints of stories such as "Lingave's Temptation" and "Dumb Kate," likewise, may have influenced Whitman's decision to reprint them, thereby putting them back into circulation as well. At the same 
time, the frequent unauthorized reprinting of Whitman's stories in periodicals may help explain why he expressed a wish to reprint them himself in Collect in an effort to "avoid" further "surreptitious issue."

The availability of many of these short fiction pieces-both the originals and the reprints - in electronic periodical databases or via other electronic archive websites also offers contemporary readers a unique chance to trace a history of Whitman's fiction as well as the relationship between the nineteenth century's "culture of reprinting" and those short stories. ${ }^{43}$ Furthermore, by collecting citations for each reprint, it is possible to supplement the bibliographies of the poet's fiction begun by an earlier generation of Whitman scholars, including those compiled by William White and Thomas Brasher, which I reference frequently in the following pages. Examining the cities, regions, dates, and, perhaps, even the occasions of the reprinting of Whitman's fiction stands to reveal a great deal about the circulation of his stories long before he began publishing his editions of Leaves of Grass. Future projects might, for example, help us understand why "Death in a School Room" was reprinted at least twelve times in Wisconsin between the years of 1856 and 1862; they might track the circulation of the same story in regional newspapers throughout New York and the Northeast; and/or they might help us to further explore the appearance of Whitman's fiction in international periodicals since his fiction was published in at least four countries in his lifetime.

Finally, there is also an opportunity and a need to examine these reprints for the purpose of discovering variations from the original publication and, by extension, charting Whitman's own process of editing the pieces. Instructors who teach Whitman in the classroom can now allow students to see not simply how widely or how often the fiction was reprinted, but they can also help students to analyze the periodical contexts - the other magazine or newspaper articles surrounding Whitman's stories - as well as the placement of Whitman's works. It is also possible to study the layout, the masthead, and even the typeface of individual periodical pages, whole issues or the entire runs of a publication. Just as Susan Belasco and Elizabeth Lorang have constructed an illuminating history of Whitman's Poems in Periodicals, it will also be worthwhile for scholars and students alike to contribute to a more complete publication history of Whitman's fiction in periodicals - a history that includes the discovery and analysis of reprints of those stories in nineteenth- and twentieth-century newspapers and magazines. ${ }^{44}$

\section{Technische Universität Dortmund}

